\title{
Measuring Industry Readiness of Engineering Students of Nagpur Region with Reference to Social Skills
}

\author{
Madhavi Wairagade, Preeti Shukla
}

\begin{abstract}
Most of the students of Engineering colleges in Vidarbha region select their employment through campus placements. It is thus the responsibility of the colleges to make the students skilled to enhance the chances of their employability. The paper divided the skill sets into and Social skillsand measured its impact on Employability Test Scores viz. Aptitude Test Score, Group Discussion Score and Personal Interview Score. It is found that social skills viz. Industry Institute Interaction and Leadership Quality of the students play an important role in deciding Employability Test Scores of the students. The results were arrived at by taking the sample 629 students of engineering colleges of Nagpur region. Hence the mapping of various parameters in their past social skill superimposed with current assessment of their potential on the basis of aptitude test, group discussion and personal interview can generate certain indicators of success in future placement/ higher education/ entrepreneurship in engineering profession.
\end{abstract}

Keywords: Employability skills, Social skills, CART Analysis

\section{INTRODUCTION:}

"What we are today is the result of what we valued yesterday. What we will be tomorrow will be the result of what we value today..." Swami Vivekananda.

Students must be given the space and scope to think and innovate, to question and to come up with solutions. This applies to both school education and higher education. The lack of ability of the student to deliver his views effectively at the interview leads to rejection of even the most brilliant candidate.

The abilityto apply the concepts learntto constantly develop innovative things and find solutions to complex problems are main factors working behind the employability of an engineer.

Revised Manuscript Received on July 25, 2019.

Madhavi Wairagade,

Research Scholar, (Management), Department of Management Studies, Dr. C. V. Raman University, Bilaspur, (C.G.)

Dr. Preeti Shukla,

Assistant Professor, Department of Management Studies, Dr. C. V. Raman University, Bilaspur, (C.G.)
India aims to become a global super power by 2025 . The current situation is alarming and the future of thousands of engineering graduate students is at stake. Every small step in the right direction by researchers to nurture and build a talented \& employable workforce will play a significant role in realizing this dream. Currently while there is no dearth of opportunities in the employment scenario, there is a serious lack of employable talent.

The growth of Engineering and Technology educational Institutes increase in multifolds in India to fulfil requirement of future technocrats. This remarkable quantitative growth of Technical Institutes has directly affected quality of technical education \& employability of engineering students.

Students on today's campuses encounter a variety of complex situations for which they are often ill-prepared by experience or individual development. The relationship between students' attitudes and values and the environment that supports or challenges them stands as a dynamic dialectic of confirmation and rejection that affects the ethical positions and choices of both the individual and the institution.

The distinctive nature of the institutional ethos affects the values and interests manifested in the campus climate and the overall effect of the college experience on the student. Value education should promote lively discussion and thoughtful reflection that leads to explore further values as a part of academics and in society, the community, and one's individual life. The process of value education involves clarifying, modeling, teaching, and asking students to role model values, and to apply them in their educational, personal and professional lives.

Campus placement activity is very important in private technical institutes for Industries, Institutes and Students. Leading ranking agencies around the world are using success in campus placement as important criteria for ranking institutes \& keep that information available on social websites. NAAC (National Assessment and Accreditation Council) and NBA (National Board of Accreditation) a self-governing body has given more marks on number of offer letters received in campus placement. Parents preferred institutes which help their wards in providing placement opportunities in multinational companies. Multinational companies fulfill their 60-70 \% entry level engineering graduate requirements by conducting campus placement drive at reputed institutes \& decide visit based on last year's placement record. 
Educational institutions should give more importance to value based education in addition to preparing the students to get more marks in examinations. Education should mould the personality of an individual. Education should be a light of knowledge which should lead the world in a right path. Education has always been concerned with broader sense of humanity, quality of human life and human excellence.

\section{REVIEW OF LITERATURE:}

Richard m. Felder, gary n. Felder, meredithmauney\& e. Jacquelindietz, “ A Longitudinal Study of Engineering Student Performance and Retention. Gender Differences in Student Performance and Attitudes", In a continuing study under way at North Carolina State University, a cohort of students took five chemical engineering courses taught by the same instructor in five consecutive semesters. This study examines gender differences in the students' academic performance, persistence in chemical engineering, and attitudes toward their education and themselves. The women in the study on average entered chemical engineering with credentials equal to or better than those of the men, but exhibited erosion relative to the men in both academic performance and confidence as they progressed through the curriculum. Possible causes of the observed disparities are suggested and remedial measures are proposed.

Australasian Journal Of Engineering Education, Published in Australia by the Australasian Association for Engineering Education Inc AAEE, 2003 ISSN 13245821, "Engineering Education - Is Problembased Or Project-Based Learning The Answer?'Julie E. Mills School of Geoscience, Minerals \& Civil Engineering University of South Australia, Adelaide, South Australia, Australia,David F. Treagust Science and Mathematics Education Centre Curtin University, Perth, Western Australia, Australia. The dominant pedagogy for engineering education still remains "chalk and talk", despite the large body of education research that demonstrates its ineffectiveness. In recent years, the engineering profession and the bodies responsible for accrediting engineering programs have called for change. This paper discusses the application of problem-based and project-based learning to engineering education, examines the difference between them. It reviews some examples of where they have been used to date and discusses the effectiveness and relevance of each method for engineering education.

The modern engineering profession deals constantly with uncertainty, with incomplete data and competing (often conflicting) demands from clients, governments, environmental groups and the general public. It requires skills in human relations as well as technical competence. Whilst trying to incorporate more "human" skills into their knowledge base and professional practice, today's engineers must also cope with continual technological and organisational change in the workplace. In addition they must cope with the commercial realities of industrial practice in the modern world, as well as the legal consequences of every professional decision they make. Despite these challenges, the predominant model of engineering education remains similar to that practiced in the 1950's - "chalk and talk", with large classes and singlediscipline, lecture-based delivery the norm, particularly in the early years of study. Developments in studentcentred learning such as problem-based and projectbased learning have so far had relatively little impact on mainstream engineering education. This paper begins by examining the critical issues for engineering education and their impact on accreditation requirements. It then looks at the nature of both problem based and project-based learning, discusses their differences and reviews examples of their application in engineering education.

MacLachlan, Anne J, "Developing Graduate Students of Color for the Professoriate in Science, Technology, Engineering, and Mathematics (STEM)", this paper presents part of the results of a completed study entitled A Longitudinal Study of Minority Ph. D.s from 19801990: Progress and Outcomes in Science and Engineering at the University of California during Graduate School and Professional Life. It focuses particularly on the graduate school experience and degree of preparation for the professoriate of African American doctoral students in the sciences and engineering, and presents the results of a survey of 33 African American STEM Ph.D.s from the University of California earned between 1980-1990. Relationships with thesis advisors and principal investigators are evaluated by the study participants in fifteen specific areas from highly-ranked intellectual development to low ranked training in grant writing. Deficits in training and socialization are discussed along with the tension between being both an African, American and a graduate student. Career choices and outcomes are presented. These findings, in conjunction with current analyses of graduate education in STEM, suggest ways in which graduate training for all could be improved.

\section{RESEARCH METHODOLOGY}

As mentioned in literatures, the focused topics are retention in engineering, process for selecting students for engineering, what makes an engineering program distinct, challenge for the 
future School of Engineering, quality of transnational engineering education, quality improvement of engineering courses, degree of preparation for the professoriate.

The present study is to evaluate the industry readiness of engineering students in Nagpur Region with reference to Social skills. The study is carried out on the basis of students' value based education by considering various parameters as well as their earlier achievements in past and present parameters like, Performance co-curricular activities, extracurricular activities, art, literary activities, other academic inputs, industry institute interaction and leadership qualities, and its impact on aptitude test, evaluation of their performance in group discussion and personal interview, which present a diverse side for the researches related to engineering career.

\section{Rationale of the study}

Nagpur region is churning out thousands of graduates every year who should ideally fill new jobs, however the reality is that many of these fresh graduates are not fully ready for the jobs that the industry is offering. In spite of having huge requirement of engineering manpower, industry finds it difficult to get suitable manpower. In this study, the various employability skills linked with the past performance of engineering students in co-curricular activities, extracurricular activities and their value based education that may likely influence their performance in campus placement are in consideration.Employability of an individual is the possession of the qualities and competencies required to meet the changing needs of employers and customers and thereby help to realize his or her aspirations and potential at work.

\section{Objectives of research}

The objective of this study is to evaluate industry readiness of Engineering students of Nagpur region, based on their earlier achievements in past and present performance, on the basis of various parameters like their performance in cocurricular activities, value based engineering education, extra-curricular activities, aptitude test, group discussion and personal interview.

Following are the objectives of this research:

1. To measure industry readiness of engineering students of Nagpur region.

2. To study the past performance of engineering students of Nagpur region in co-curricular and extra-curricular activities.

3. To study the present performance of engineering students of Nagpur region in aptitude test.
4. To study the present performance of engineering students of Nagpur region in group discussion and personal interview.

\section{HYPOTHESIS OF RESEARCH}

H1: In Nagpur region industry readiness of Engineering students, is dependent on value based education and excellence in Engineering.

H2: In Nagpur region, the past performance of engineering students in co-curricular activities is having positive impact on their present performance in aptitude test, group discussion \& personal interview.

H3: In Nagpur region, the past performance of engineering students in extra curricular activities is having positive impact on their present performance in aptitude test, group discussion \& personal interview.

\section{Sample of the study}

The sample of $20 \%$ i.e. 629 students of Final Year of Bachelor of Engineering/ Bachelor of Technology from approximately 12 engineering colleges in Nagpur Region are considered under study. Structured questionnaires have been distributed during their campus placement to collect primary data. Social skills under consideration viz. Performance co-curricular activities, extracurricular activities, art, literary activities, other academic inputs, industry institute interaction and leadership qualities have been on credit score of 1 to 10 based on their participation and performance in the activity and employability skills like Aptitude, Communication, Technical \& Personality is evaluated.

The sampling technique used was Random sampling technique. The students who have applied and appeared for campus placements are considered for the purpose of analysis. Selection of sample is done based on criteria of availability of data viz. aptitude scores, group discussion score, participation in curricular and extra-curricular activities etc.

\section{Statistical tools}

For the purpose of analysis of data statistical tools have been divided into two categories viz. Descriptive statistics and Inferential statistics.

\section{Descriptive Statistics}

Descriptive statistics involves the presentation and description of data. The data collected is quantitatively described with its main features. The descriptive statistics aims to summarize the sample. The measures used in descriptive statistics are

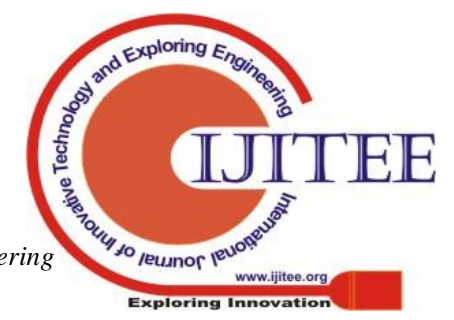


central tendency and measures of variability or dispersion. Measures of central tendency include the mean, median and mode, while measures of variability include the standard deviation or variance, the minimum and maximum values of the variables, kurtosis and skewness.

\section{Inferential Statistics}

Unlike descriptive statistics, inferential statistics are developed on the basis of probability theory. Inferential are meant to draw conclusions out of data set.

\section{Regression Analysis}

\section{Model I, II and III:}

Social Skills and students' performance in employability test specially the one which measure Social skills of the students. Social skills of the student is measured with their participation in Curricular and Extra-curricular activities, Art, Other academic input, Literary activities Industry institute interaction and Leadership qualities exhibited by the student in past. Three mutually exclusive models are constructed to test the impact of Social skills on scores of each tests viz. Aptitude, Group Discussion and Personal Interview.

$$
\begin{aligned}
Y=\beta_{0}+\beta_{1} X_{1}+ & \beta_{2} X_{2}+\beta_{3} X_{3}+\beta_{4} X_{4}+\beta_{5} X_{5}+\beta_{6} X_{6} \\
& +\beta_{7} X_{7}+\varepsilon
\end{aligned}
$$

Where,

$Y=$ Aptitude Test Score/ Group Discussion Score/ Personal Interview Score

$\beta=$ Regression coefficient

$X_{l}=$ Curricular activity credit score

$X_{2}=$ Extra-curricular activity credit score

$X_{3}=$ Credits score for participation in Art related activities

$X_{4}=$ Credit score for Literary activity

$X_{5}=$ Credit score for other academic input

$x_{6}=$ Credit score for participation in Industry-

Institution Interaction programme

$x_{X 7}=$ Credits for exhibiting Leadership qualities

$\varepsilon=$ Error term

\section{Limitations of the study:}

As the study is based on primary data, some limitations are bound to exist which are follows:

1. Analysis and conclusions drawn are based on the finite sample of 629 students. Generalisations are done based on the confident level of $95 \%$.
2. Analysis is done based on the data provided by respondent students is assumed to be true which may be biased in nature.

3. The study is limited to Nagpur region and hence the findings drawn may not be applicable to other regions.

4. The study is conducted for engineering college students only.

\section{DATA ANALYSIS AND INTERPRETATION}

The present study has the aim of measuring the performances of students in placements with mathematical models. The main goal is to measure the employability of engineering students and their aspirations in order to have fruitful and successful career. Hence the mapping of various parameters in their past educational career, superimposed with current assessment of their potential on the basis of aptitude test, group discussion and personal interview can generate certain indicators of success in future placement/ higher education/ entrepreneurship in engineering profession.

Since Engineering represents an important part in the employability, the researcher focused on this domain, with the aim of evaluating the performance of students in this domain. The importance of this research lies in its uniqueness and effectiveness, as the performance indicators were analyzed with multiple regression analysis and its relationship with past performance of students in social skills.

This research has attempted to measure the ability of the students to succeed in engineering education \& perhaps practicing engineering beyond education. Data has been collected about students' performance in social skills vis.- avis. present performance of students in comprehensive aptitude test to analyze engineering aptitude indicating intelligence of the students. Table 1 below shows the descriptive statistics of the variables. 
Table 1: Descriptive Statistics

\begin{tabular}{|l|l|l|l|l|l|l|l|}
\hline & $\mathrm{N}$ & Mean & Std. Deviation & \multicolumn{2}{l|}{ Skewness } & \multicolumn{2}{l|}{ Kurtosis } \\
\cline { 2 - 9 } & Statistic & Statistic & Statistic & Statistic & Std. Error & Statistic & Std. Error \\
\hline Aptitude test score & 629 & 6.5517 & 1.38208 & -.344 & .097 & .396 & .195 \\
\hline Group discussion score & 629 & 5.7059 & 1.83499 & -.517 & .097 & -.355 & .195 \\
\hline Personal interview score & 629 & 5.3482 & 1.34777 & -.358 & .097 & -.218 & .195 \\
\hline Curricular activity & 629 & 6.1113 & 3.08278 & -1.236 & .097 & -.098 & .195 \\
\hline Extra curricular activity & 629 & 5.1876 & 3.94465 & -.415 & .097 & -1.634 & .195 \\
\hline Art & 629 & 1.5056 & .50669 & -.096 & .097 & -1.808 & .195 \\
\hline Literary activity & 629 & 3.3990 & 3.80095 & .289 & .097 & -1.834 & .195 \\
\hline Other academic input & 629 & 4.4102 & 3.68725 & -.232 & .097 & -1.765 & .195 \\
\hline Industry institute interaction & 629 & 5.3943 & 2.38767 & -.598 & .097 & -.351 & .195 \\
\hline Leadership qualities & 629 & 5.3545 & 2.07193 & -.578 & .097 & -.449 & .195 \\
\hline Valid N (listwise) & 629 & & & & & & \\
\hline
\end{tabular}

Data has been collected on the performance \& participation of students in various extra \& co curricular activities, other leadership qualities, industry institution interaction of students. The impacts of these activities are studied on the present performance of students in group discussions \& personal interview, in order to analyze their engineering aptitude indicating social skills.

This analysis generally belongs to the multivariate methods, and it is also an explanatory method of analysis. Regression analysis describes the relationship between a dependent variable and several independent variables. The dependent variable consist viz. Aptitude test score, Group discussion score and Personal interview score while the independent variables were performance \& participation of students in various extra \& co curricular activities, other leadership qualities, industry institution interaction of students (showing social skills).

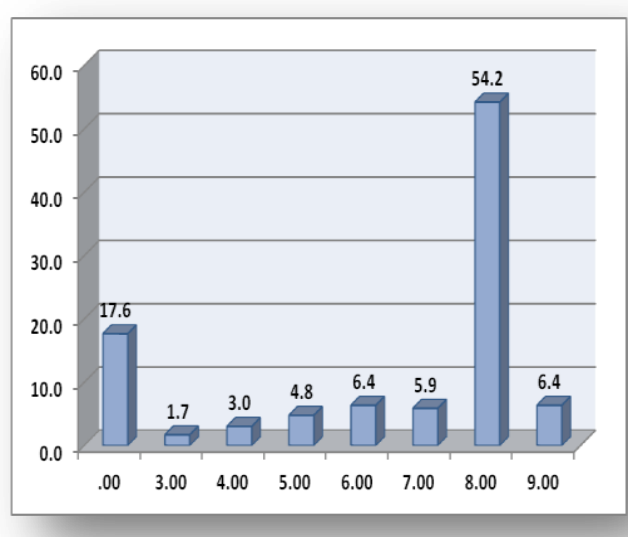

Figure 1: Distribution of Curricular Activity Credit Score among students (in \%)

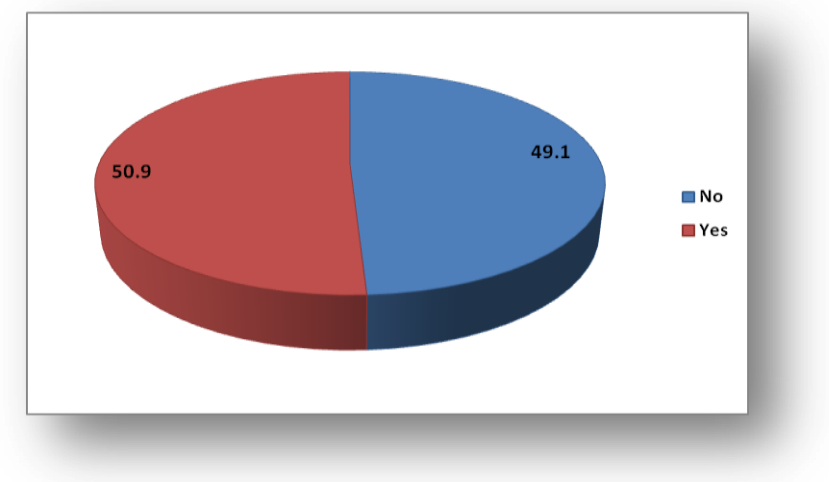

Figure 3: Distribution of students (in \%) who participated in Artistic activities

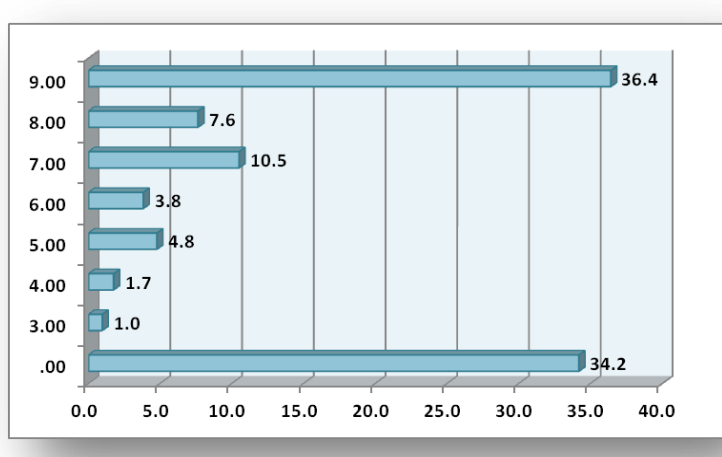

Figure 2: Distribution of Extra-Curricular Activity Credit Score among students (in \%) 


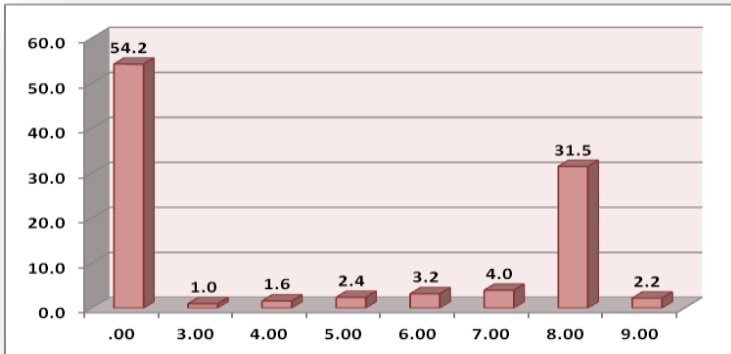

Figure 4: Distribution of Literary Activity Credit Score among students (in \%)

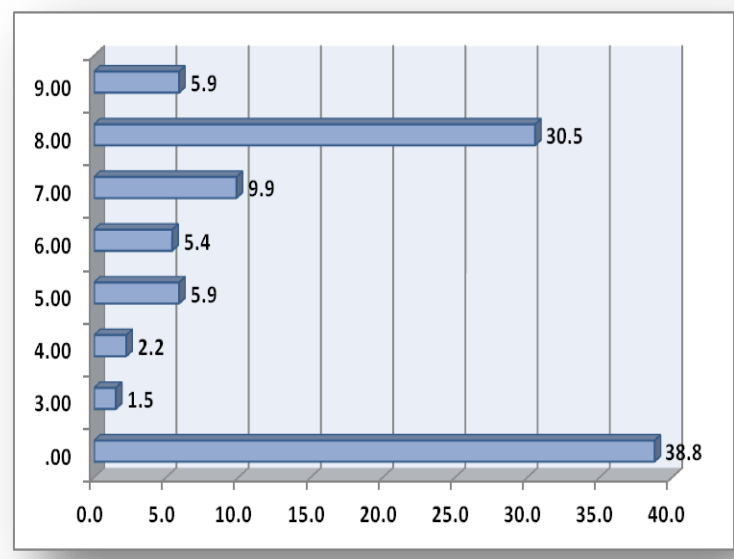

Figure 5: Distribution of Other Academic Input Credit Score among students (in \%)

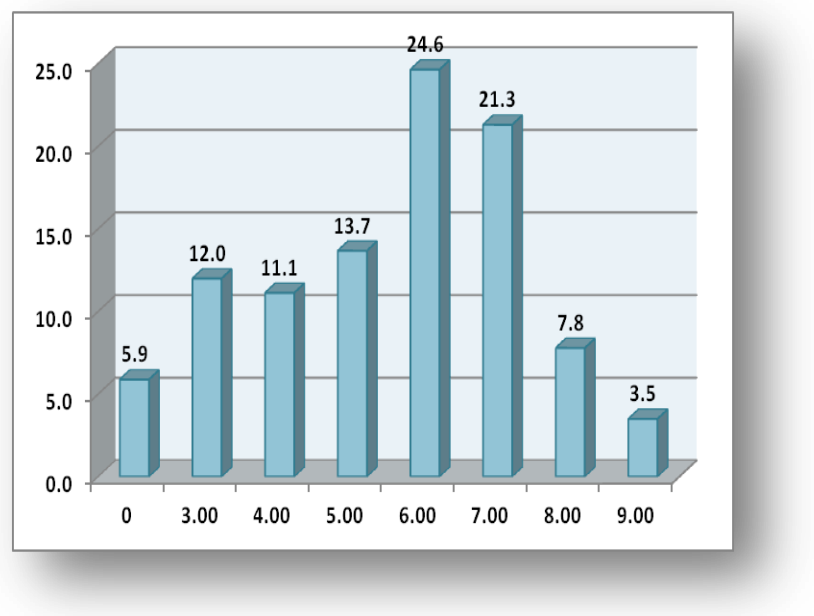

Figure 7: Distribution of Leadership Quality Credit Score among students (in \%)

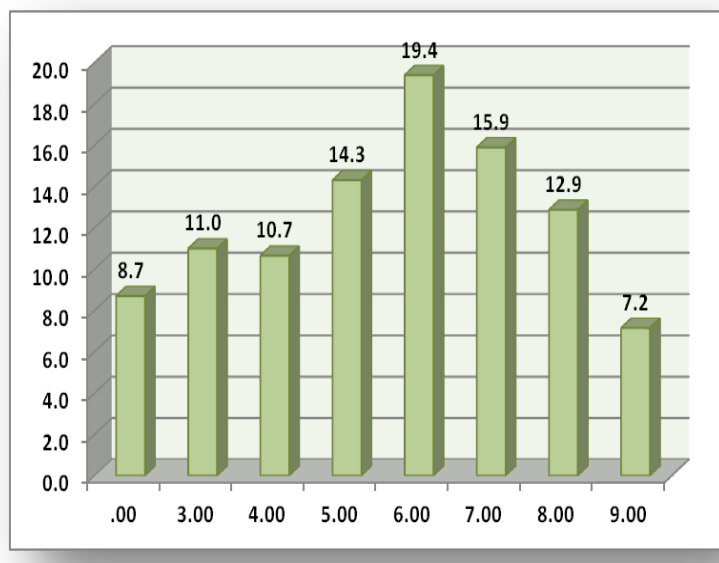

Figure 6: Distribution of Industry-Institute Interaction Credit Score among students (in \%)

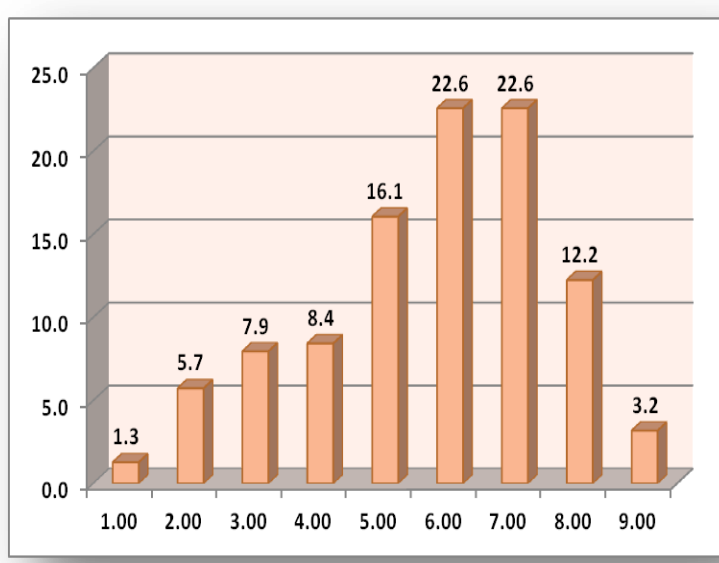

Figure 8: Distribution of Group Discussion Score among students (in \%)

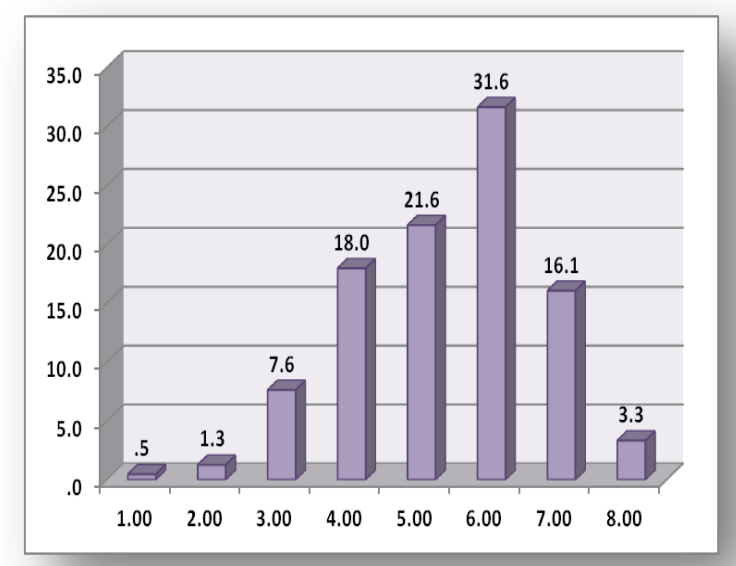

Figure 9: Distribution of Personal Interview Score among students (in \%)

Published By: 


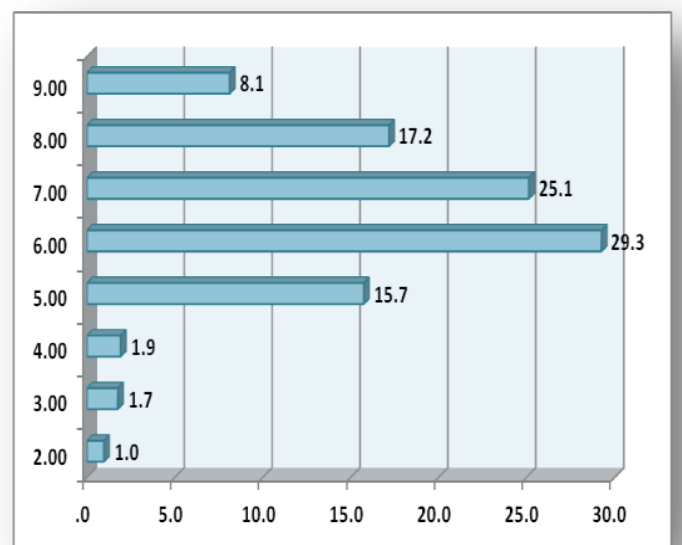

Figure 10: Distribution of Aptitude Test Score among students (in \%)

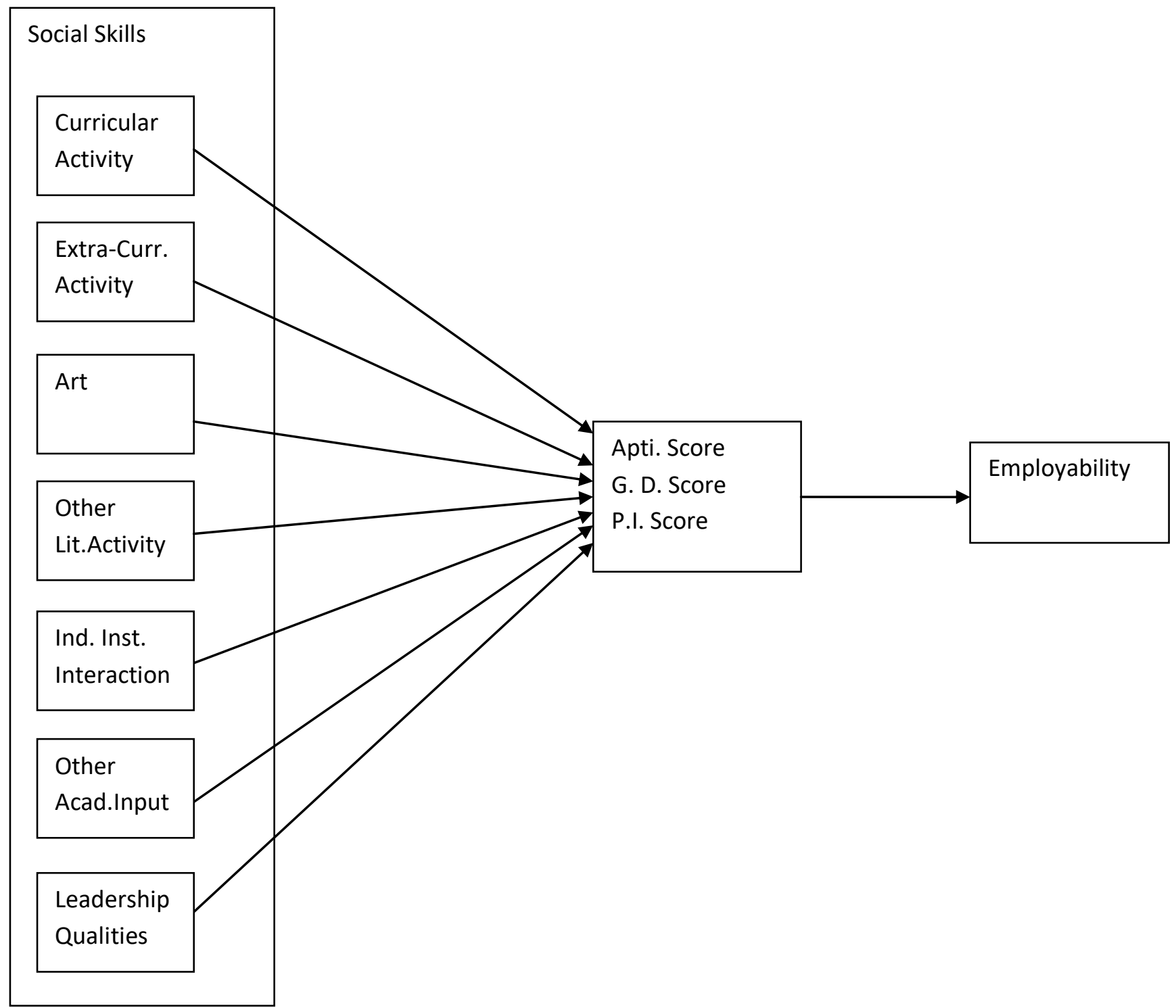

Figure 11: Structural diagram

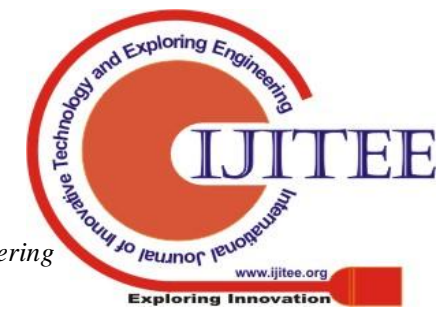




\section{Impact of Social Skills on Aptitude Test Score, Group Discussion Score and Personal Interview Score.}

When an engineer is employed by a company these scores will provide guidelines about his engineering aptitude. Those who have higher scores will be able to carry out their responsibilities more judiciously. Further break up of the score in Intellectual Abilities \& Social Skills can be used to identify a suitable person. Depending upon the requirement of job profile i.e. if intellectual work like design \& development is more important then the intelligence aptitude score of the person will play a vital role $\&$ if the profile involves managerial qualities or team efforts then the social skills aptitude will be more important.

Apart from Academic Intelligence, literature suggests that there is relationship between Social Skills and students' performance in employability test specially the one which measure Social skills of the students. Social skills of the student is measured with their participation in Curricular and Extra-curricular activities, Art, Other academic input, Literary activities Industry institute interaction and Leadership qualities exhibited by the student in past. Three mutually exclusive models are constructed to test the impact of Social skills on scores of each tests viz. Aptitude, Group Discussion and Personal Interview.

It was hypothesised that social skills will have low impact on Aptitude score and more on Group discussion and Personal interview score of the student. Regression model summary and ANOVA results of all three models viz. Model I, Model II and Model III where dependent variable is Aptitude Score, Group Discussion Score and Personal Interview Score respectively is shown in table no.3. It is found that $\mathrm{R}^{2}$ value of regression Model I where Aptitude score is dependent variable, is 0.195 . It means only $19.5 \%$ of the variance in aptitude score has been explained by all the seven independent variable. However, the variance is found to be significant $(\mathrm{F}=3.949)$ at $5 \%$ level of significance (p-value<0.05).

In Model II, Group discussion is taken as dependent variable, $59.40 \%$ of the variance in it has been explained by all independent variables and it is significant at 5\% level. Similarly, in Model III, Personal interview score of the student is taken as dependent variable and $46.80 \%$ of the variance in personal interview score has been explained by all the independent variables which is also statistically significant at $5 \%$ level.

Hence, it can be concluded that out of three dependent variables i.e. Aptitude score, Group discussion score and Personal interview score, it is Group Discussion score that is mostly determined by the social skills of the student.
Model I: This model takes into account Aptitude Score of the student as dependent variable and Curricular and Extracurricular activities, Art, Other academic input, Literary activities Industry institute interaction and Leadership qualities exhibited by the student in pas as independent variables.

Curricular activities involve Paper presentation, Participation in quiz, Projects, Debate, Public speaking and Extempore. Extra-curricular activities involve participation of student in Sports and Cultural activities such as Dance, Drama and Music. Art includes student's participation in Drawing, Painting, Collections and Photography. Literary activities include Reading and Writing. Other academic input includes computer languages and Spoken languages. Industry-Institute interaction includes participation in Summer training, Industrial visits, Step up programme and live projects. Leadership qualities are measured by participation or role of student as Monitor, President Secretary etc. at school, college, NCC, NSS, Scout/Guide, any club or Social Service Club.

\begin{tabular}{|l|l|l|l|}
\hline \multicolumn{4}{|l|}{ Table 2: Model Summary and ANOVA } \\
\hline & $\mathrm{R}^{2}$ & F-value & $\mathrm{p}$-value \\
\hline $\begin{array}{l}\text { Aptitude } \\
\text { Score }\end{array}$ & 0.195 & 3.494 & $.001^{\mathrm{b}}$ \\
\hline $\begin{array}{l}\text { Group } \\
\text { Discussion } \\
\text { Score }\end{array}$ & & & \\
\hline $\begin{array}{l}\text { Personal } \\
\text { Interview } \\
\text { Score }\end{array}$ & 0.594 & 48.283 & $.000^{\mathrm{b}}$ \\
\hline $\begin{array}{l}\text { (Table value of } \mathrm{F}=2.62 \text { at } 5 \% \\
\text { significance) level of }\end{array}$ \\
\hline
\end{tabular}

The credit scores were determined for each activity out of 10 based on students' past involvement and performance in various activities and are regressed against their score in Aptitude, Group Discussion and Personal interview.

Regression coefficients (Beta, $\beta$ ) of model I, II and III are given in table no.3. Regression coefficients show impact of change in dependent variable with a unit of change in independent variable.

It is found as per table no. 3 that out of seven independent variables which shows social skills of the students and when Aptitude score is a dependent variable, learning Other Academic inputs like Computer language and Spoken languages is an important determinant of aptitude score. Beta value for Other 
academic input is found to be 0.106 with t-value of 2.473 and is significant at $5 \%$ level as p-value is 0.014 . Similarly, for Industry Institute Interaction beta value is found to be 0.083 with t-value of 2.053 and p-value is 0.041 and is therefore significant at $5 \%$ level. Participation in programs and activities that show leadership quality is also found to be significant negative contributor to aptitude score since, beta value is -0.102 which is significant at $5 \%$ level.

Except participation in Art which is negatively related to aptitude score, all other social skills are found not to be significantly related to Aptitude test score.

\section{Model II:}

It is found as per table 3 that out of seven independent variables which shows social skills of the students and when
Group Discussion score is a dependent variable, Curricular activity, Art, Industry Institute Interaction and Leadership qualities are important determinants of Group Discussion score. Beta value for Curricular activity is found to be 0.318 with t-value of 9.260 and is significant at $5 \%$ level as pvalue is 0.000 . Similarly, for Industry Institute Interaction beta value is found to be 0.071 with t-value of 2.152 and $\mathrm{p}$ value is 0.032 and is therefore significant at $5 \%$ level. Participation in programs and activities that show leadership quality is also found to be significant contributor to aptitude score since, beta value is 0.373 which is significant at $5 \%$ level. Similarly, participation in Artistic activities plays role in determining Group Discussion score of the candidate. All other social skills are found not to be significantly related to Group Discussion score.

\begin{tabular}{|c|c|c|c|c|c|c|c|c|c|c|}
\hline & & \multicolumn{3}{|c|}{ Aptitude Score (Model I) } & \multicolumn{3}{|c|}{$\begin{array}{l}\text { Group Discussion } \\
\text { (Model II) }\end{array}$} & \multicolumn{3}{|c|}{$\begin{array}{lll}\text { Personal Interview } & \text { Score } \\
\text { (Model III) } & \end{array}$} \\
\hline Sr. No. & $\begin{array}{l}\text { Social } \\
\text { Skills }\end{array}$ & Beta & t-value & p-value & Beta & t-value & p-value & Beta & t-value & p-value \\
\hline 1 & $\begin{array}{l}\text { Curricular } \\
\text { activity }\end{array}$ & 0.055 & 1.309 & 0.191 & 0.318 & 9.26 & $\mathbf{0}$ & 0.026 & 0.679 & 0.497 \\
\hline 2 & $\begin{array}{l}\text { Extra- } \\
\text { cultural } \\
\text { activity }\end{array}$ & 0.06 & 1.403 & 0.161 & 0.03 & 0.86 & 0.39 & 0.278 & 7.274 & 0 \\
\hline 3 & Art & -0.007 & -0.167 & 0.867 & 0.101 & 2.843 & 0.005 & -0.021 & -0.55 & 0.583 \\
\hline 4 & $\begin{array}{l}\text { literary } \\
\text { activity }\end{array}$ & 0.037 & 0.833 & 0.405 & 0.041 & 1.106 & 0.269 & 0.253 & 6.548 & 0 \\
\hline 5 & $\begin{array}{l}\text { other } \\
\text { academic } \\
\text { input }\end{array}$ & 0.106 & 2.473 & 0.014 & 0.034 & 0.959 & 0.338 & 0.251 & 6.501 & $\mathbf{0}$ \\
\hline 6 & $\begin{array}{l}\text { industry } \\
\text { institute } \\
\text { interaction }\end{array}$ & 0.083 & 2.053 & 0.041 & 0.071 & 2.152 & 0.032 & 0.154 & 4.225 & $\mathbf{0}$ \\
\hline 7 & $\begin{array}{l}\text { leadership } \\
\text { qualities }\end{array}$ & 0.102 & 2.469 & 0.014 & 0.373 & 11.024 & 0 & 0.02 & 0.533 & 0.594 \\
\hline
\end{tabular}

Table no.3: Regression coefficients

\section{Model III:}

It is found as per table 4 that out of seven independent variables which shows social skills of the students and when Personal Interview score is a dependent variable, Extra- Curricular activity, Other academic input and, Industry Institute Interaction are important determinants for Personal Interview score. Beta value for ExtraCurricular activity is found to be 0.278 with t-value of 7.274 and is significant at $5 \%$ level as p-value is 0.000 . Literary Activities viz. Reading and Writing have significant relationship with Personal Interview score as Beta value is 0.253 which is significant at $5 \%$ level. Similarly, for Other Academic Input, beta value is found to be 0.251 and significant at $5 \%$, Industry Institute Interaction beta value is found to be 0.154 with $t$-value of
4.225 and p-value is 0.000 and is therefore significant at $5 \%$ level. All other social skills are found not to be significantly related to Group Discussion score.

From the above results, it can be concluded that Other Academic Input and Industry Institute Interaction is andeterminant of Aptitude score and Leadership qualities are inversely related to Aptitude test score and found to be significant while it is directly and significantly related to the Group Discussion score of the candidate. Extracurricular activities also plays an important role in determining the Personal Interview Score of Engineering Students' employability.

In short, the impact of Academic and Social

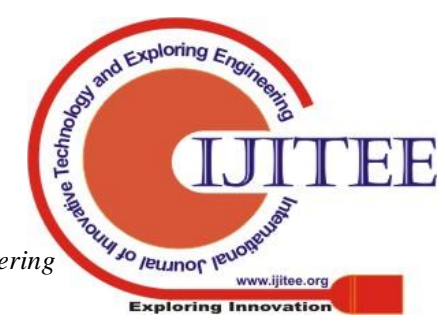


skills with Aptitude Test Score, Group Discussion Score and Personal Interview Score for Employability of
Engineering students have been summarized in the following table no. 4

Table no. 4: Impact of Social Skills on Employability Test Scores.

\begin{tabular}{|l|l|l|l|}
\hline \multirow{2}{*}{ Social Skills } & \multicolumn{3}{|l|}{ Employability Test Score } \\
\cline { 2 - 4 } & $\begin{array}{l}\text { Aptitude Test } \\
\text { Score }\end{array}$ & $\begin{array}{l}\text { Group } \\
\text { Discussion } \\
\text { Score }\end{array}$ & $\begin{array}{l}\text { Personal Interview } \\
\text { Score }\end{array}$ \\
\hline Curricular activity & No & Yes & No \\
\hline Extra- cultural activity & No & No & Yes \\
\hline Art & No & Yes & No \\
\hline literary activity & No & No & Yes \\
\hline other academic input & Yes & No & Yes \\
\hline industry institute interaction & Yes & Yes & No \\
\hline leadership qualities & Yes & Yes & \\
\hline
\end{tabular}

\section{CART Analysis}

It is found as per CART Analysis shown in fig. 12 that Leadership qualities exhibited by the students in their past academic life plays significant role in determining the Aptitude Score of the students specially those who have participated in leadership activities and performed better in those activities. It is also noticed that the relation between credits scored by the students have significant relationship with aptitude scores as chi-square value is found to be significant at $5 \%$ level of significance.

In turn, students who have scored 4, 6 and 3 credits in leadership activities have relation with their credit score in activities related to Industry Institute interaction at 5\% level of significance. 


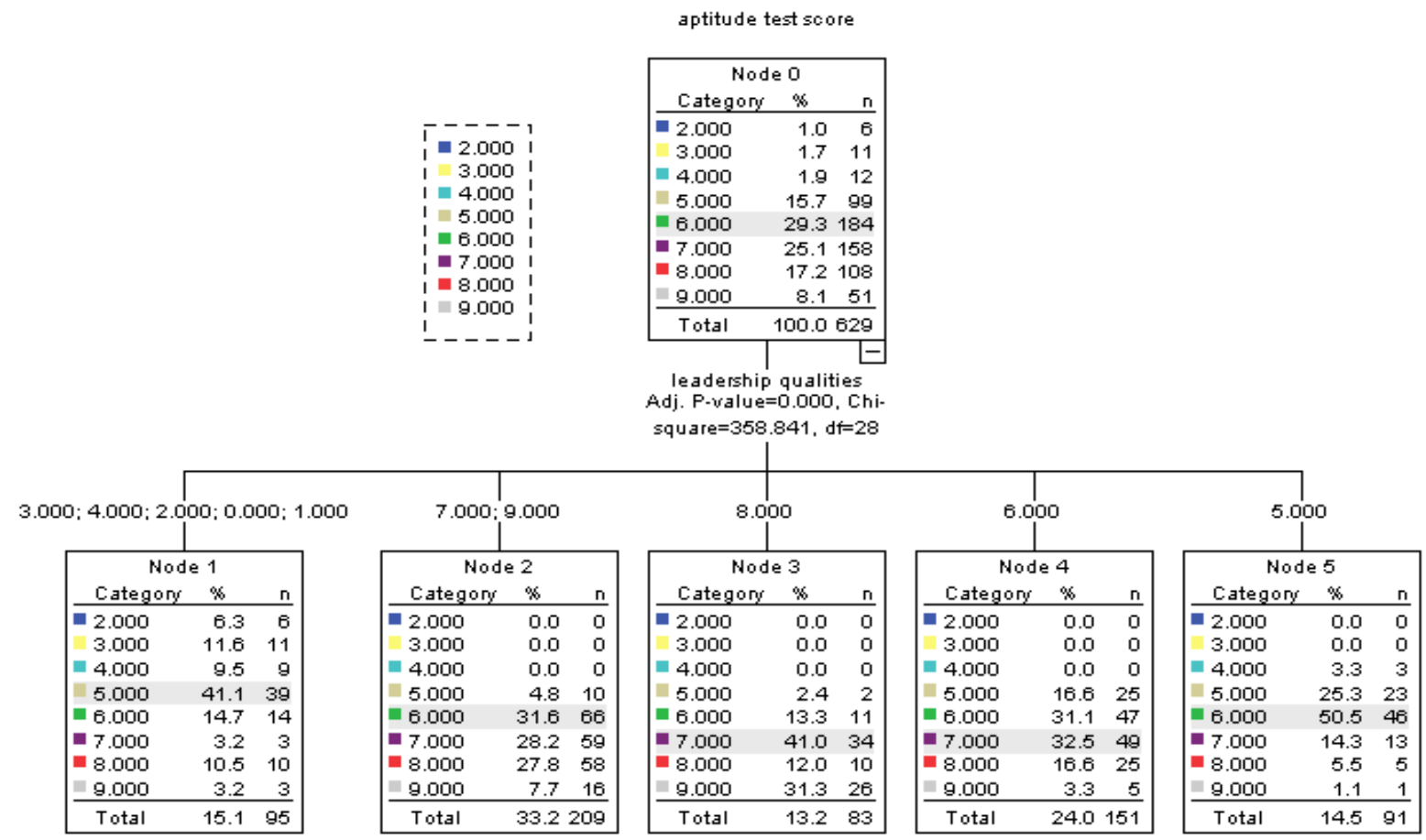

Figure 12: CART Analysis with Aptitude Score as Dependent Variable

It is also found from fig. 13 that leadership qualities play an important role in determining the GD score of the students at $5 \%$ level of significance which in turn is mainly determined by curricular activities as compared to art related activities.
Fig. 14 shows that Other Academic Inputs of students prove to be the significant determinant of Personal Interview Score at $5 \%$ level of significance which in turn is determined by students performance in Extra-curricular activities. 


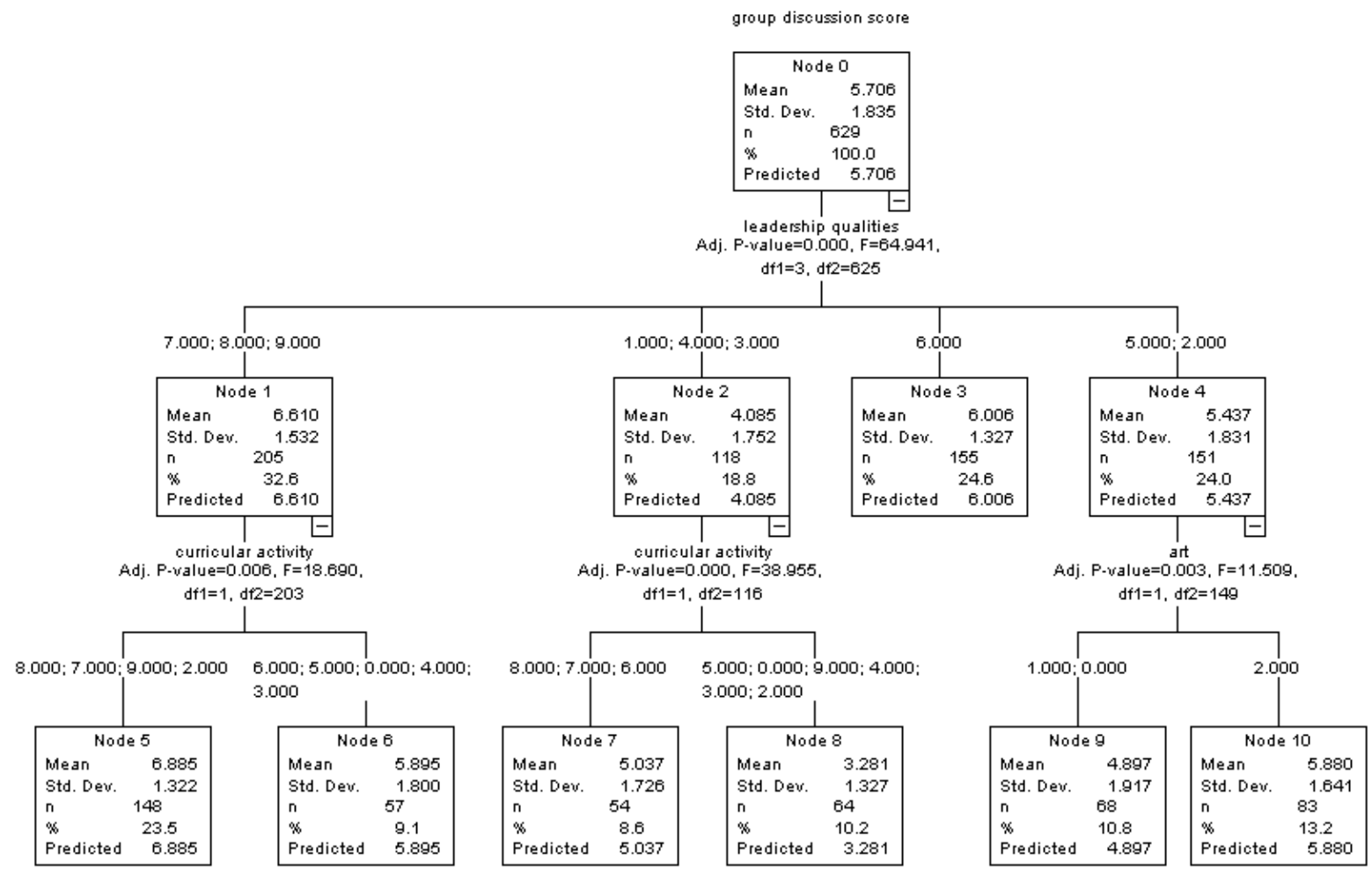

Figure 13: CART Analysis with Group Discussion Score as Dependent Variable

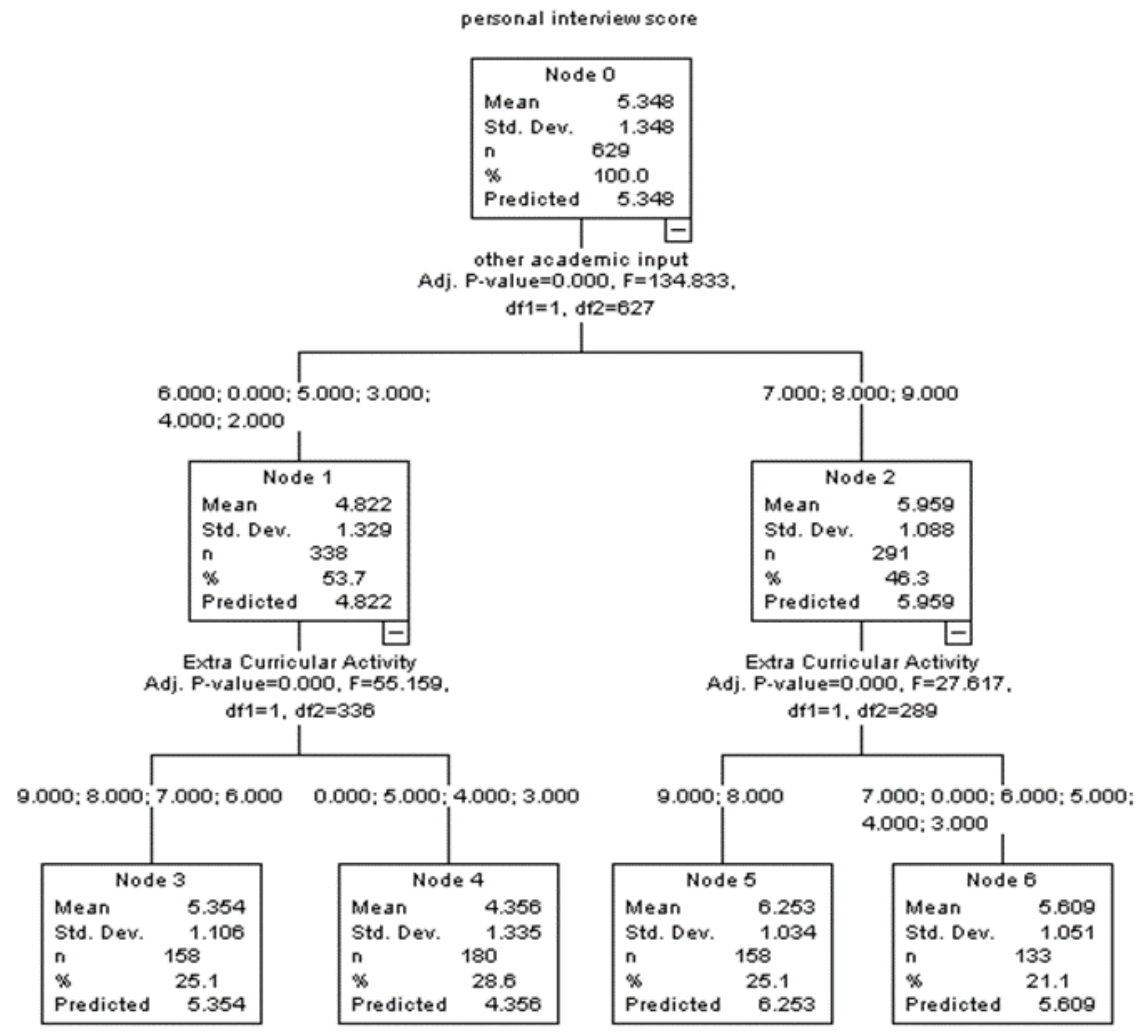

Figure 14: CART Analysis with Personal Interview Score as Dependent Variable 


\section{CONCLUSION:}

The paper tried to measure the impact of Social Skills of the engineering students on their employability through employability tests viz. Aptitude test, Group Discussion Score and Personal Interview Score. Social skills viz. Industry Institute Interaction through summer internship and Leadership qualities acquired throughout their academic life also plays an important role in determining employability of engineering students as it has significant determinant of Aptitude test and Group discussion. Leadership qualities acquired during the academic life as Monitor of the class, Participation in National Service Scheme, National Cadet Course etc. instil a sense of confidence and integrity in students which get reflected during the group discussion. These value based qualities are important in employment.

Thus, when an engineer is employed by a company, these scores will provide guidelines about his engineering aptitude. Those who have higher scores will be able to carry out their responsibilities more judiciously.Further breakup of the score in Social Skills can be used to identify a suitable person. Depending upon the requirement of job profile i.e. if intellectual work like design \& development is more important then the intelligence aptitude score of the person will play a vital role $\&$ if the profile involves managerial qualities or team efforts then the social skills aptitude will be more important.

\section{REFERENCES:}

[1]. RICHARD M. FELDER, GARY N. FELDER, MEREDITH MAUNEY \& E. JACQUELIN DIETZ, “ A Longitudinal Study of Engineering Student Performance and Retention. Gender Differences in Student Performance and Attitudes", In a continuing study under way at North Carolina State University.

[2]. Journal of Engineering Education, 84(2), 151-163 (1995). AUSTRALASIAN JOURNAL OF ENGINEERING EDUCATION, Published in Australia by the Australasian Association for Engineering Education Inc AAEE, 2003 ISSN 1324-5821, "ENGINEERING EDUCATION - IS PROBLEMBASED OR PROJECTBASED LEARNING THE ANSWER?" Julie E. Mills School of Geoliescience, Minerals \& Civil Engineering University of South Australia, Adelaide, South Australia, Australia, David F. Treagust Science and Mathematics Education Centre Curtin University, Perth, Western Australia, Australia

[3]. MacLachlan, Anne J, Center for Studies in Higher Education, UC Berkeley Publication Date: 03-01-2006 Series: Research and Occasional Papers Series Permalink: http://escholarship.org/uc/item/3892k4rm, "Developing Graduate Students of Color for the Professoriate in Science, Technology, Engineering, and Mathematics (STEM)"

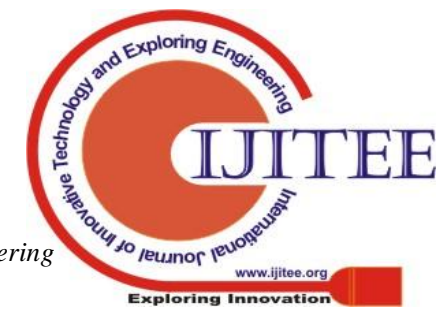

